\title{
Playful intervention with chronically-ill children: promoting coping
}

\author{
Intervenção lúdica a crianças com doença crônica: \\ promovendo o enfrentamento
}

Intervención lúdica a niños con enfermedad crónica:

promoviendo el enfrentamiento

\author{
Flávia Moura de Moura ${ }^{a}$ \\ Áderson Luiz Costa Júniorb \\ Meryeli Santos de Araújo Dantasc \\ Gilvan da Cruz Barbosa Araújo ${ }^{d}$ \\ Neusa Collet ${ }^{\mathrm{e}}$
}

\begin{abstract}
Chronic diseases can adversely affect the development process of children. This qualitative, action-research study had the aim to analyze the effects of activities in the manual "Como Hóspede no Hospital" (As a patient in the hospital) on the coping process of children with chronic diseases. Study participants included six children and adolescents aged seven to 13 years, who suffered from a chronic disease. Data were collected in the pediatric clinic of a public hospital in the Brazilian state of Paraiba, through participant observation and individual sessions with activities from the manual. Data interpretation followed the principles of thematic analysis. The activities from the manual encouraged participants' search for information about their disease and treatment, and increased their interest and participation in their health care process, thereby contributing to better coping. The study points to the need for comprehensive care for children with chronic diseases.
\end{abstract}

Descriptors: Chronic disease. Child. Comprehensive health care.

\section{RESUMO}

As doenças crônicas podem gerar consequências adversas ao processo de desenvolvimento infantil. 0 estudo teve por objetivo analisar os efeitos da realização de atividades do manual "Como Hóspede no Hospital" sobre o processo de enfrentamento de crianças afetadas por doenças crônicas. Pesquisa qualitativa do tipo pesquisa-ação. Participaram do estudo seis crianças e adolescentes, entre 7 e 13 anos, com doenças crônicas. Os dados foram coletados na clínica pediátrica de um hospital público do estado da Parába, por meio de observações participantes e sessões individuais com a aplicação de atividades do manual. A interpretação dos dados seguiu os princípios da análise temática. As atividades do manual estimularam a busca de informação sobre a doença e o tratamento, e aumentaram o interesse e a participação das crianças e dos adolescentes em envolver-se no cuidado à saúde, contribuindo para um melhor enfrentamento. Aponta-se a necessidade de cuidados integrais às crianças com doenças crônicas.

Descritores: Doença crônica. Criança. Assistência integral a saúde.

\section{RESUMEN}

Las enfermedades crónicas pueden tener consecuencias adversas para el proceso de desarrollo del niño. El estudio tuvo como objetivo analizar los efectos de la realización de actividades del guía "Cómo huésped en el Hospital" en el proceso de enfrentamiento de los niños afectados por enfermedades crónicas. Investigación cualitativa del tipo investigación-acción. El estudio incluyó a seis niños y adolescentes de 7 a 13 años con enfermedades crónicas. Los datos fueron recogidos en la clínica pediátrica de un hospital público en el estado de Paraíba a través de la observación participante y sesiones individuales con la aplicación de las actividades del guía. La interpretación de los datos siguió los principios de análisis temático. Las actividades del guía alientan la búsqueda de información sobre la enfermedad y el tratamiento y aumentaron el interés y la participación de los niños y adolescentes en involucrarse en el cuidado de la salud, lo que contribuye a un mejor enfrentamiento. Se señala la necesidad de una atención integral a los niños con enfermedades crónicas.

Descriptores: Enfermedad crónica. Niño. Atención integral de salud.
D0l: http://dx.doi.org/10.1590/19831447.2014.02.41822 


\section{口INTRODUCTION}

Chronic diseases generally entail a set of conditions that are related to multiple causes, usually with uncertain prognoses, long or indefinite duration, and varied and unstable clinical courses with periods of crisis and physical and/or functional disabilities. Many chronic diseases require interventions with technologies that may be associated with changes in lifestyle, in a process of care that does not always lead to cure.(1)

Studies show that chronic diseases in childhood tend to cause changes to the everyday and adaptation needs, such as following diets, physical constraints, ${ }^{(2)}$ impaired schooling, ${ }^{(3)}$ repeated exposure to invasive and/or painful procedures, $^{(4)}$ frequent hospitalization ${ }^{(5)}$, bodily changes and negative feelings towards oneself.(2)

Due to the potential compromises and changes to everyday life caused by chronic diseases, care needs to meet the specific psychosocial needs of children and adolescents, and it is essential that health care teams identify such needs.

When care is focused on children and adolescents, it is essential to make resources available that facilitate social interaction between patients and health care professionals, and communication about the disease and treatment, especially about what is expected of the patient, ${ }^{(6)}$ and unconditional positive attention to the needs of everyone involved, including patients and families.

Recreational resources can be used to this end because they provide, in addition to pleasure and entertainment, the opportunity to express thoughts and feelings, knowledge acquisition and behavioral changes, in order to stimulate quality of life indicators.(7)

Sources of children's literature can serve as an aid to address diagnosis and treatment, and for health education action. ${ }^{(8)}$ This study used a health care manual targeting hospitalized children and adolescents titled "Como hóspede no hospital" (As a patient in the hospital), containing interactive activities and tasks that involve thinking, writing, drawing, coloring, sentence completion, and the creation of stories. The manual was proposed in order to facilitate children's expression of feelings about their illness and hospitalization, to aid their acquisition of knowledge of hospital routines and specific situations related to hospitalization, and to promote the adoption of more effective coping strategies to their situation. In addition to being a playful mediator, each activity addresses issues related to potentially stressful events and the suffering of children and adolescents in relation to their experiences of chronic illness and hospitalization.
This study presents results of the master's degree thesis entitled, "O lúdico no enfrentamento da hospitalização de crianças com doenças crônicas" (Playing in coping with hospitalization by children with chronic diseases). ${ }^{(9)}$ The question that guided this study was: How does the health care manual "As a patient in the hospital" influence the process of coping by children and adolescents hospitalized for treatment of chronic diseases? The aim of the study was to analyze the effects of performing activities from the manual "As a patient in the hospital" on the coping process of children and adolescents hospitalized for treatment of chronic diseases.

\section{METHODOLOGY}

This study had a qualitative research design and employed an action-research methodology. This is an intervention methodology that seeks to diagnose a specific phenomenon in order to achieve a practical result. In addition to the production of knowledge, this type of research also proposes planned action. ${ }^{(10)}$

The study was conducted at the pediatric clinic of a federal public teaching hospital in the state of Paraíba, between January and April of 2009. Inclusion criteria for participants were children and adolescents with chronic disease; aged between seven and 13 years; hospitalized in the unit under study; literate and able to write and draw; with a general health condition that was not serious; and demonstrating social interaction with the environment. Children and adolescents with mental disorders and/or intellectual, visual or hearing disabilities were excluded. The criterion for termination of data collection was sufficiency. ${ }^{(11)}$

The study included six children and adolescents with the following chronic diseases: nephrotic syndrome, sickle cell anemia, thalassemia, lupus and scleroderma. Although they could be of both sexes, all of the study participants were female, due to the profile of hospitalized patients in the target age group during the period of data collection.

In compliance with resolution no. 196/96 of the Brazilian National Health Council, the project was submitted to the Research Ethics Committee of the hospital, and approved under protocol no. 136/08. After acceptance by the children and their guardians to participate in the research, the latter signed a free and informed consent form.

In the first phase of the study, children who met the inclusion criteria were identified. In the second phase, contact was made with family members and guardians of the 
children in order to obtain information about their general health conditions, and how they coped with illness and hospitalization.

In the third phase, participant observation on the behavior of the children in the hospital was conducted for one day, and this was recorded in a field diary.

In the fourth phase, individual sessions to apply activities from the manual were carried out with the children, all of which were audio recorded. The sessions with the children took place daily and had different durations in order to adhere to their needs and availability.

In the fifth phase, another day of participant observation was undertaken to analyze the effects of the activities from the manual on the participants'strategies for coping with hospitalization.

With the transcriptions of the audio recordings and field diary entries in hand, the research proceeded to organization of empirical material produced for analysis, using the following steps: sorting, classification and final analysis of the data. ${ }^{(11)}$ The procedure followed the principles of thematic analysis, which seeks to reveal the core meanings of a communication, the presence of which indicates a significance to the objective to be achieved. ${ }^{(11)}$ The initial classification was performed with the thorough and repeated reading of all of the material. Then the themes were grouped to construct the core meaning: the children talking about chronic disease and their care. To ensure the anonymity of participants, in the presentation of the results they were identified by the names of Disney princesses, followed by their age in years, and accompanied by the letter "a". In the transcriptions, the children's statements were represented by the letter " $\mathrm{C}$ ", and those of the researcher by the letter "R." The identities of other people mentioned were also concealed. As a linguistic resource, the term "children" is used to refer to both the children and/or adolescents participating in the study.

\section{RESULTS AND DISCUSSION}

In order to analyze the understanding and knowledge that the patients have about their disease, and the care requirements to maintain a good quality of life, as well as to identify their feelings and fears, it is essential to support the construction of a comprehensive therapeutic and educational project aimed at the psychosocial needs of the chronically-ill children and adolescents. This procedure may generate other psychosocial intervention projects, to be performed by the entire health care team of the hospital, such as improvement of the communication process between patients and physicians.(7)
Activity 01 from the manual was performed with all the participants, which asked them to write the name of their disease and the affected parts of their body. In addition to the name of the disease, the children also referred to events related to the onset of the illness, limitations imposed by the illness and their meanings, the cause of hospitalization, and the care they need to get well. Such information can assist in a psychosocial diagnosis, and facilitate the planning of interventions by the health care team. In this study, the children were able to name their disease, and some were even able to provide explanations about it.

\section{Scleroderma [...] is aging of the skin (Cinderella-11y).}

I have sickle cell anemia [...] my cells, due to anemia, they are not shaped like those of people who do not have anemia. If I don't drink a lot of fluid, they end up attaching to one another, if I drink liquid they stay separated, they stay, like, swimming, they don't join together, they don't cause pain, and when they join together it causes pain in my back and joints (Mulan-13y).

My illness is nephrotic syndrome [...] The doctor said it was like a strainer that's not straining, which has some holes in it, she said it is passing, but I didn't really understand (Belle-12y).

Belle's statement shows that the physician explained the disease with the use of a metaphor to facilitate understanding, yet the child did not comprehend what she was told.

This study's interventions with Belle attempted to provide her with greater knowledge about anemia, as she had expressed not understanding which part of the body was no sick or what could happen.

$$
\begin{aligned}
& R \text { - What parts of the body are responsible for peeing? } \\
& C \text { - The kidneys? } \\
& R \text { - Do you know what the kidneys do? } \\
& C-\text { No } \\
& R-\text { They filter the urine, the pee. The disease you have is in } \\
& \text { the kidneys. } \\
& C \text { - And what is it? (Belle-12y). }
\end{aligned}
$$

In general, a chronic condition has the characteristic of not being temporary.(1) Therefore, understanding the need for prolonged treatment and the characteristics of treatment can promote the development of long-term coping strategies, greater participation of the children and adoles- 
cents in their treatment, as well as enable their acquisition of skills for self-care, with positive implications for autonomy and social ability.

Lupus [...] is a chronic disease that can be treated [...]. A disease that takes a while to... which has a prolonged treatment [...] and that has a cure (Jasmine-12y).

During the activities, the need for prolonged treatment of chronic illness was reinforced with each child; however, in regard to the cure for lupus, it was emphasized that it is not possible to this date, as it was important that the patient have real knowledge about her condition.

In regard to identification of the disease in their bodies, the children indicated the body parts that were affected at the time, especially by pain. This is understandable, as in the child's perception, these are the body parts that indicate the presence of the disease.

My hand hurts when I do this (moves hand forward and backward), my knee hurts when I move it, and my neck hurts when I turn it (Cinderella-11y).

\section{C-My face, arms and legs only hurt a little. \\ $R$ - What is in those parts of your body? \\ $C$ - Lupus (Jasmine-12y).}

Although scleroderma and lupus are systemic diseases that may impair various organs, the children with these diseases referred only to bullous lesions and pain in their hands. Nevertheless, the carrier of sickle cell anemia, who had lived with the disease for more time and had experienced episodes of exacerbation/crisis, was able to distinguish between the body part affected at the time of the crisis and complications resulting from the disease, such as osteoarticular and abdominal pain, and blood problems resulting from the disease.

$C$ - The body part...When I'm in anemia crisis I feel pain in my joints and back [...].

$R$ - What is the body part that gets sick when you have anemia [...]?

C-The blood? (Mulan-12y).

The children's statements indicate that they have some knowledge about their illness; however, it is clear that there are gaps or lack of understanding, which is reflected in the form of less effective coping strategies.

Some children were able to name the drugs they take, and talked about some precautions that they need to follow in relation to diet, water intake and diuretic foods. Nevertheless, it is important to ask whether the children really understand these precautions, or merely reproduce what they hear.

The interventions with the children were conducted to present and discuss aspects of their illness and treatment in a comprehensible manner to them. Contents emerged during the sessions and were integrated into the activity in process. The activities were also aimed at promoting a more active approach to the health-disease process, and the patients were encouraged to seek information from the health care team, and thus gain increased autonomy in their self-care.

C - Take the medicines, do physiotherapy and do the exams. [...]

$R$ - Which medicine do you take?

$C-$ Idon't know, my mom gives it to me (Cinderella-11a).

It is notable that responsibility for the children's health care often falls upon their mothers. Even if a child has cognitive and psychosocial(12) conditions to understand her diagnosis and its implications, as well as the ability to assume responsibility for some of her care, with the assistance and guidance of the family there is a tendency towards overprotection, which may arise due to uncertainties about the course of the disease and fear of her death. (12) This behavior is reinforced, in particular by the mother, who, due to an overprotective attitude toward the child, makes her less responsive, and hinders her development of autonomy. . $^{(2)}$

For children and adolescents to cope more effectively, it is essential that they actively participate in their treatment process. They need to be partners in the production and information of care, and not mere recipients of it..(14) In order to cope effectively, children with chronic diseases need to become active and informed individuals who seek out health care services, and have the motivation, information, skills and confidence to effectively make decisions about their health care, and manage their chronic condition. In the case of children/adolescents, these decisions should be made together with their families. ${ }^{(14)}$ By means of listening, health care professionals can grasp the demands of these patients and their families in every encounter of care, identifying their specific needs, and increasing the level of trust in the mutual relationship of health care.

In the proposed construction of health care networks ${ }^{(15)}$ and care of chronic conditions, supported self-care is valued, ${ }^{(16)}$ the focus of which is on cooperation between the health care team, children/adolescents with chronic dis- 
ease and their families, in order to jointly define problems, set priorities, propose goals, develop care plans, and monitor the results.

In 2011, the Brazilian government released the Strategic Action Plan Against Non-Communicable Chronic Diseases, effective from 2011-2022. This plan is based on a comprehensive approach to care of chronic, non-communicable diseases, including prevention and the promotion of comprehensive care.(17) Although the plan specifically addresses four major groups of diseases that affect the adult population, it is important to emphasize concern with chronic diseases that affect children and adolescents. These present different clinical features that, if not properly managed, can lead to significant harm to their development process in early and adult life, their families, and expenses to the health care system.

Encouraging children to talk about the care that they need can help them to perceive themselves as responsible for their own treatment, and thereby develop autonomy. Furthermore, through the patients' reports, the health care team can identify inappropriate care behaviors in the home environment, and guide the required behavioral changes.

$R$ - What was your treatment like before coming to the hospital?

C - It was taking the medicine and using sunscreen [...] I put it on at six in the morning, before going to school, again when I got home, after showering and before going to sleep.

$R$ - Who told you to put it on before bedtime?

C - My mom, who also used it, not to scratch. (Jasmine-12y).

During the sessions and through observation, gaps in knowledge about the disease and treatment were evident, along with little involvement of the children in their care, and inefficient communication and distance in relation to the health care team. It was found that all of the children had an interest in obtaining more information, but did not perceive the health care team as an accessible source of information and support.

Similarly, another study ${ }^{(18)}$ showed that knowledge of families is generally insufficient to develop adequate home care for chronically-ill children. According to the authors, the information is obtained by families in a subtle manner, and is difficult to grasp due to overly-technical content. The participants in this study also demonstrated insufficient knowledge. Lack of knowledge can pose a health risk by leading patients and families to improper behavior and/ or delays in the development process.
Management of a chronic disease often involves changes in lifestyle habits, which require both physical and psychological efforts. Thus, medical information needs to be explained to patients according to their level of cognitive understanding, because if they do not understand the importance of a particular care orientation, they may have difficulties in following the treatment and maintaining a good quality of life. ${ }^{(19)}$

Due to the findings of the study as to the existence of knowledge gaps, inefficient communication and distancing of the children in relation to their treatment, the interventions were undertaken with the intention to increase their participation in their treatment. To this end, the activities requested the patients to write down what they were feeling, both emotionally and physically. Through these activities, it was expected that the participants could see themselves as part of the care process, and would be encouraged to communicate their feelings, doubts, fears, etc.

For children with chronic diseases in which the illness presents a series of recurring episodes of crisis, body awareness is crucial to identify signs and symptoms that may precede a crisis event, and even prevent worsening of their clinical status.

C - [...] now I'm not feeling anything, but before I came, I had so much pain in my bladder. (Mulan-13y).

Thus, the authors emphasize the importance of preparing patients to communicate with the health care team, based on the provision of more accurate information from them as well. Nonetheless, this communication is only possible if a caring, positive and trusting relationship is established between those involved in the process, and with information consistent with the child's level of understanding.

\section{$R$ - What do you feel differently in your body? \\ $C$ - Just this here (shows skin) \\ $R$ - Just the bubbles? And do these bubbles provoke some feeling? \\ C-Oh! It itches, it itches a lot. \\ $R$ - You can say that these bubbles are very itchy, and that is different. (Jasmine-12y).}

The patients often presented a more participatory attitude towards their care process, but the health care team discouraged this behavior and did not pay attention to the patients' actions (or did not know how to pay attention) and did not listen intently to the children's 
needs, even though these were presented in a clear and direct manner.

C - I was feeling a lot of heartburn, I talked to the doctor (resident) and was going to see if he could prescribe a drug, and then he did not do it. I spoke with Dr. "B" (pediatrician), and she also did not give me a medicine, then the night doctor (on night duty) gave me some (Mulan-13y).

Comprehensive health care for children and adolescents should be conceived of in a broader context that goes beyond providing instructions about treatment to be followed. Children and adolescents need to understand the aspects of the treatment and both positive and negative effects on their lives, ${ }^{(20)}$ in order to make the best choices according to their wishes and needs. Like the proposal of the manual used in this study, a therapeutic project should be built with the participation of all of those involved and giving relevance to attributed meanings, the knowledge and understanding of the care the patients need in order to maintain a good quality of life.

Interventions guided by the activities of the manual seem to have contributed to make the children more active in their health and treatment process, promoting their acquisition of more efficient coping strategies. Nevertheless, the production of comprehensive care for children with chronic diseases requires health care professionals to have willingness and sensitivity to deal with the anxieties and desires of the patients and their families.

\section{GINAL CONSIDERATIONS}

The development of the activities in the manual "As a patient in the hospital" increased the likelihood of the children and adolescents becoming more involved in their treatment process, and contributed to the development of more efficient strategies for coping with their disease, including learning about their illness and treatment, developing autonomy and becoming more active in their health care process, also acquiring skills necessary to maintain their quality of life.

Even highlighting the potential benefits that can be obtained using the manual as a resource in the comprehensive care of chronically-ill children and adolescents, the authors emphasize the importance of participation of the family and staff in the care process. Therefore, it is necessary that the health care team is prepared and acts proactively when interacting with children and adolescents with chronic disease and their families, providing meaningful information, support and resources necessary in the provision of high-quality care. Playful resources have been shown to be important tools to mediate this process.

Although the results of this study demonstrate the importance of using playful resources in the care of hospitalized children and adolescents with chronic disease, further research is necessary to systematically evaluate the effectiveness of these resources, and to plan interventions according to the unique psychosocial needs of this population. This study highlights the importance of using playful strategies that facilitate the understanding of children and adolescents with chronic illness, encouraging them to participate in their health care process, bearing in mind that they must live with the disease for a long period of time.

\section{口EFERENCES}

1. Ministério da Saúde (BR). Secretaria de Atenção em Saúde. Departamento de Ações Programáticas Estratégicas. Diretrizes nacionais para a atenção integral à saúde de adolescentes e jovens na promoção, proteção e recuperação da saúde. Brasília (DF) 2010. 132 p. : il. - (Série A. Normas e Manuais Técnicos).

2. Nóbrega RD, Collet N, Gomes, IP, Holanda, ER, Araújo, YB. Criança em idade escolar hospitalizada: significado da condição crônica. Texto Contexto Enferm. 2010;19(3):425-33.

3. Schineder KLK, Martini JG. Cotidiano do adolescente com doença crônica. Texto Contexto Enferm. 2011;20(Esp):194-204.

4. Cicogna EC, Nascimento LC, Lima RAG. Crianças e adolescente com câncer: experiências com a quimioterapia. Rev Latino Am Enferm. 2010;18(5):864-72.

5. Frota MA, Machado JC, Martins MC, Vasconcelos VM, Landim FLP. Qualidade de vida da criança com insuficiência renal crônica. Esc Anna Nery Rev Enferm. 2012;14(3):527-33.

6. Kohlsdorf, M, Costa Junior, AL. Comunicação em pediatria: revisão sistemática de literatura. Est Psic Campinas. 2013;30(4):539-552.

7. Mota $A B$, Enumo SRF. Intervenção lúdica para 0 enfrentamento da hospitalização em crianças com câncer. Psicol Teoria Pesq. 2010;26(3):445-54.

8. Brodani JP, Pedro ENR. A história infantil como recurso na compreensão do processo saúde-doença pela criança com HIV. Rev Gaúcha Enferm. 2013;34(1):14-21.

9. Moura FM, 0 lúdico no enfrentamento da hospitalização de crianças com doenças crônicas [dissertação]. João Pessoa (PB): Programa de Pós-Graduação em Enfermagem, Universidade Federal da Paraíba; 2009.

10. Minayo MCS. 0 desafio do conhecimento: pesquisa qualitativa em saúde. 11ª ed. São Paulo: Hucitec-Abrasco; 2010

11. Minayo MCS, Assis SG, Souza, ER. Avaliação por triangulação de métodos: abordagem de programas sociais. 1a ed. Rio de Janeiro: Fiocruz; 2005.

12. Bee H. A criança em desenvolvimento. 12a ed. Porto Alegre: Artmed; 2011.

13. Pizzignacco TP, Mello DF, Lima RG. A experiência da doença na fibrose cística: caminhos para o cuidado integral. Rev Esc Enferm USP. 2011;45(3):638-44.

14. Montovani MF, Mendes FRP, Ulbrich EM, Bandeira JM, Fusuma F, Gaio DM. As representações dos usuários sobre a doença crônica e a prática educativa. Rev Gaúcha Enferm. 2011:32(1):622-8.

15. Mendes EV. As redes de atenção à saúde. Ciênc Saúde Coletiva. 2010;15(5):2297-305.

16. Mendes EV. 0 cuidado das condições crônicas na atenção primária à saúde: 0 imperativo da consolidação da estratégia da saúde da família. Brasília: Organização Pan-Americana da Saúde; 2012. 
17. Malta DC, Moraes Neto OL, Silva Júnior JB. Apresentação do plano de ações estratégicas para 0 enfrentamento das doenças crônicas não transmissíveis no Brasil, 2011 a 2022. Epidemiol Serv Saúde. 2011;20(2):425-38.

18. Araújo YB, Collet N, Moura FM, Nóbrega RD. Conhecimento da família acerca da condição crônica na infância. Texto Contexto Enferm. 2009;18(3):498-505.
19. Souza MLXF, Silva KL, Nóbrega MML, Collet N. Déficits de autocuidado em crianças e adolescentes com doença renal crônica. Texto Contexto Enferm. 2012;21(1):95-102.

20. Gabarra LM, Crepaldi MA. A comunicação médico-paciente pediátrico-família na perspectiva da criança. Psicol Argum. 2011;29(65):209-18.

\section{Author's address:}

Flávia Moura de Moura

Rua da Aurora, 201/608, Miramar

58043-902, João Pessoa, PB

E-mail: flavia.m.moura@uol.com.br
Received: 13.08.2013

Approved: 09.05.2014

92

Rev Gaúcha Enferm. 2014 jun;35(2):86-92. 